http://jmscr.igmpublication.org/home/ ISSN (e)-2347-176x ISSN (p) 2455-0450 crossref DOI: https://dx.doi.org/10.18535/jmscr/v8i1.12

\title{
Histomorphological analysis of testicular and paratesticular lesions - 4 year study from a tertiary centre in South India
}

\author{
Authors \\ Dr Sheeja.S ${ }^{1}$, Dr Renu Thambi ${ }^{* *}$, Dr Suresh Bhatt ${ }^{3}$, Dr Subitha K. ${ }^{4}$, \\ Dr Sankar Sundaram ${ }^{5}$ \\ ${ }^{1,2}$ Associate Professor, Pathology, GMC, Kottayam, ${ }^{3}$ Professor, Urology, GMC, Kottayam \\ ${ }^{4}$ Associate Professor, GMC, Trichur, ${ }^{5}$ Professor, Pathology, GMC, Kottayam \\ Corresponding Author \\ Dr Renu Thambi
}

\begin{abstract}
Background: Testis is the site for a large number of neoplastic and non-neoplastic lesions of varied etiology which can occur in any age group. Testicular tumours are rare, affecting adolescents and young adults. Only limited literature is available on the epidemiology of testicular and paratesticular lesions from South India.

Aim: A detailed 4 year histopathological analysis of testicular and paratesticular lesions including testicular tumours were undertaken.

Materials and Methods: A total of 160 orchidectomy cases studied with retrieved blocks and slides from the department. A detailed clinicopathological correlation done. Serological markers and Immunohistochemistry done in required cases.

Results: Our analysis showed $87.5 \%$ non neoplastic lesions with torsion testis being the most common followed by atrophic testis and tuberculous epididymo-orchitis. Of the neoplastic lesions (12.5\%) malignant tumours were common compared to benign tumours and germ cell tumour constituted the predominant malignant lesion.

Conclusion: The distribution of testicular lesions in patients attending our institution were comparable with available worldwide data.
\end{abstract}

Keywords: Testicular lesions, paratesticular lesions, Non neoplastic and neoplastic, TB orchitis

\section{Introduction}

Testis and paratesticular region are affected by several clinicopathological conditions broadly grouped into non neoplastic and neoplastic diseases. These lesions occur in a wide range of age group with scrotal swelling and pain as the major presenting complaints. Non-neoplastic lesions are more common and testicular torsion being the commonest type. Torsion of testis is a surgical emergency leading to orchidectomy in 10-25 years of age.

Testicular carcinoma follows a reverse pattern compared to most other cancers, with decreasing incidence rate with increasing age. According to Globacon 2018 testicular tumours form $0.4 \%$ of total cancers with 71105 new cases, ranking $28^{\text {th }}$ in tumour position ${ }^{[1,2]}$. Globacon India 2018 data depicts 4414 new cases of testicular tumours $\left(0.38 \%\right.$ total cancers) and ranks $31^{\text {st }}$ position $^{[3]}$. 
Based on Globocan 2012 database, incidence and mortality trends over globe shows a distinct variation in last 10 years over 5 continents. An increase in incidence was seen in Europe with the highest incidence in Southern Europe and a stable incidence in China. A lower incidence was noted in Asian and African population with a higher mortality rate ${ }^{[4,5]}$.

In 2016, WHO has classified testicular and paratesticular neoplasms into various subgroups with seminomas being the commonest type of germ cell tumours followed by mixed germ cell tumour. Non seminomatous germ cell tumours mainly includes yolk sac tumour, embryonal carcinoma, choriocarcinoma ,teratoma which are highly aggressive. Non germ cell tumors like sertoli leydig cells are generally benign, constituting $5 \%$ of tumours and associated with endocrinological syndromes ${ }^{[6]}$.

Neoplastic and nonneoplastic lesions of paratesticular region can be cystic or solid masses. The common cystic lesions include hydroceles, epididymal cysts and varicoceles. Most of the paratesticular solid masses are benign, most common being lipomas and adenomatoid tumour. Rarely malignant tumours like rhabdomyosarcoma, liposarcoma, leiomyosarcoma and mesothelioma can occur ${ }^{[7,8]}$.

Orchidectomy / high inguinal orchidectomy with retroperitoneal lymph node dissection done for non neoplastic/neoplastic lesions respectively with adjuvant chemoradiation depending upon the histological type and stage. Despite new techniques in imaging and tumour marker assay, pathologist plays an important role in accurate classification, subtyping and staging of tumors and identifying prognostic parameters. The present study is an attempt to identify the age groups, laterality, associated risk factors, histomorphological appearance with special reference to the testicular neoplasms.

\section{Materials and Methods}

The study was conducted at a tertiary care centre in South India. We did a retrospective analysis of the data on testicular lesions obtained from the hospital cancer registry and histopathology reports in the department of pathology during the four year study period (June 2013 - May 2017). Clinical details, investigations including radiological findings, available serum tumour marker levels and operative findings of all cases of testicular lesions were collected. The serum markers human chorionic gonadotropin (betahCG), alpha fetoprotein (AFP) and serum lactate dehydrogenase $(\mathrm{LDH})$ were done in all suspected cases of malignancy.

All salient features of gross specimens received in $10 \%$ buffered neutral formalin was noted .Gross examination findings such as external surface, tunica albugenia, site of the lesion, size, colour, consistency, necrosis, haemorrhage, involvement of epididymas, spermatic cord and resected margins were studied. For neoplastic lesions, multiple representative tissue sections were made from every $1 \mathrm{~cm}$ thickness of the tumor. Tissue sections from the adjacent testicular tissue, epididymis, spermatic cord, resected margins, and lymph nodes if available were also studied. We retrieved the blocks and slides of these cases and reviewed them systematically to form a specific histopathological diagnosis. Histopathological reports were correlated with serum tumour markers and immunohistochemical markers were done in tissue sections for relevant cases.

The data collected was analysed with SPSS software version 17. Strict confidentiality of patient information was maintained while handling the data sets. Those cases with incomplete data were excluded from the study. This study was approved by the Institutional Review Board (IEC No:56/16).

\section{Results}

A total of 160 cases of testicular and paratesticular lesions were analysed over a period of four years from June 2013 -May 2017. Most common age groups affected were 10-20 years followed by 21 30 years. Lesions showed a predominant left side involvement $(57 \%)$ and bilateral lesions were 
observed in $2.2 \%$. The commonest presenting complaints were testicular swelling (84.4\%) followed by pain $(52.5 \%)$. The specimens studied showed testicular $(76 \%)$ epididymal $(14.6 \%)$ or epididymo-testicular (9.4\%) involvement. Lesions were grouped into neoplastic and non neoplastic. Non-neoplastic lesions constituted 140 of 160 cases $(87.5 \%)$ (figure 1).

Among the non neoplastic lesions torsion testis in $2^{\text {nd }}$ decade of life was the commonest cause for orchidectomy in our setting constituting $46.4 \%$. Other non neoplastic lesions seen were atrophic testis and tuberculous epididymo-orchitis, constituting $12.86 \%$ and $12.14 \%$ respectively. Undescended testis $(3.57 \%)$ were in the age range from 10 months to 35 years. One case was a 35 year old patient who showed bilateral undescended testis. None of these cases in our study showed any association with testicular malignancy.

Neoplasms constituted 20 cases of total testicular and paratesticular lesions with malignant cases forming $75 \%$ (15 cases) and benign forming 25\% (5 cases). Tumours were predominantly left sided (53.8\%). Testicular tumours were classified according to WHO 2016. The most common malignant tumours seen were germ cell tumours constituting $60 \%$ (12 cases) of neoplasms. Seminoma was the predominant germ cell tumour forming $30 \%$ (6 cases) of total malignant tumours followed by 3 cases of mixed germ cell tumours, 2 Yolksac tumours and 1case of tetratoma.

Seminomas were seen in the with ages range of 15 to 72 years. Majority of the cases showed enlarged testis with solid, grey-white, circumscribed mass with size ranging from 1.5$10 \mathrm{~cm}$. Two cases of seminoma, one in 72 year old and other aged 38 years showed ill circumscribed, variegated with extensive areas of hemorrhage and necrosis. These tumours had extra testicular extension into the tunica vaginalis and multiple tumour emboli. 2 cases showed germ cell neoplasia insitu (GCNIC) Lymphoid aggregate and granuloma formation was seen in 2 cases.
Non seminomatous germ cell tumours were in equal proportion as the seminomas ( 6 cases). All the cases encountered in our study were right sided. Two cases of Yolk sac tumour, one in 68 yr old and other in 3 year old, and case of teratoma in a 43 year old patient. One of the two cases of nonseminomatous MGCT seen in a 21 years old patient was large $(8.5 \mathrm{~cm})$ haemorragic mass with multiple cystic spaces invading the tunica albugenia. Microscopy showed yolk sac elements with teratomatous areas with SchillerDuval bodies and multiple tumour emboli. In the other case was $6.5 \mathrm{~cm}$ in size with teratomatous, yolk sac and choriocarcinomatous areas. One case of seminomatous MGCT in a 28 year old man measured $1.2 \mathrm{~cm}$ in size with seminomatous elements with syncytiotrophoblaic differentiation and teratomatous elements, high $\beta-\mathrm{hCG}$ and showed GCNIC.

Non germ cell tumours included one sex cordstromal tumour of Leydig cell subtype and 2 cases of lymphoma. Leydig cell tumour was seen at 55 years of age as a circumscribed yellowish nodule of $3 \mathrm{~cm}$ size. Microscopy showed large polygonal cells with eosinophillic cytoplasm and round central nucleus. Non-Hodgkin's lymphoma of diffuse large B cell type both in left testis was confirmed by IHC studies in patients of age 88 and 68 years.

There were five paratesticular tumours- three leiomyoma, one leiomyosarcoma and one case of inflammatory myofibroblastic tumour. Paratesticular leiomyoma presented as whitish nodules. One case in a 23 year old man was a mass measuring $7 \mathrm{~cm} \times 6.5 \mathrm{~cm}$ with testicular tissue pushed aside with grey white trabeculated appearance on cut section. Microscopy showed spindle cell neoplasm with stroma showing myxoid change,hyalinisation and calcification with atrophic tubules. Histopathology and IHC study showed SMA positive and CD34 negative.

A large right sided scrotal mass, $13 \times 8.5 \mathrm{~cm}$ of 32 year old patient whose serum tumour markers were within normal limits. On cut section, whitish whorled with focal yellowish areas. Microscopy 
showed infiltrating neoplasm with spindle cells with abundant cytoplasm and eccentrically placed pleomorphic nuclei arranged in diffuse sheets. Stroma showed extensive areas of necrosis and mitosis was 1-2/HPF. A histopathological diagnosis of malignant spindle cell neoplasm, possibly leiomyosarcoma was made and further confirmed with IHC and cytochemistry.

A 35 year man presented with sudden onset right sided testicular pain and swelling. The swelling persisted even after the cessation of pain. On ultrasonography, a small hypoechoeic lesion in the upper half of right testis was noted. Orchidectomy specimen showed a fairly circumscribed greywhite lesion of $4 \times 3 \times 3 \mathrm{~cm}$ in the upper end of testis inseperable from epididymis. Histopathology showed a chronic inflammatory lesion predominantly of plasma cells with dense fibrosis. Histopathological diagnosis was inflammatory myofibroblastic tumour (IMT).

Table 1 Comparison of testicular and paratesticular lesions in various studies

\begin{tabular}{|c|c|c|c|c|}
\hline Lesions & $\begin{array}{c}\text { Sheeja et al } \\
(2019)\end{array}$ & $\begin{array}{cc}\text { Hemavathi } & \text { Reddy et } \\
\text { al (2016) }\end{array}$ & $\begin{array}{c}\text { Mahesh et al } \\
\text { (2013) }\end{array}$ & $\begin{array}{c}\text { Sundari Devi et al } \\
(2015)\end{array}$ \\
\hline Study duration & 4 years & 2 yrs & 2.5 years & 5 years \\
\hline Centre & $\begin{array}{c}\text { Kerala, } \\
\text { India }\end{array}$ & Karnataka, India & $\begin{array}{l}\text { Gujarat, } \\
\text { India }\end{array}$ & $\begin{array}{l}\text { Telangana, } \\
\text { India }\end{array}$ \\
\hline Number of cases & 160 & 100 & 100 & 119 \\
\hline $\begin{array}{l}\text { Neoplastic: } \\
\text { nonneoplastic lesions }\end{array}$ & $\begin{array}{c}20 / 140 \\
1: 7\end{array}$ & $\begin{array}{c}14 / 86 \\
1: 6\end{array}$ & $\begin{array}{l}15 / 85 \\
1: 5.7\end{array}$ & $\begin{array}{c}7 / 112 \\
1: 16\end{array}$ \\
\hline $\begin{array}{ll}\text { Most } & \text { common age } \\
\text { group for neoplastic } \\
\text { and } \\
\text { lesions }\end{array}$ & $\begin{array}{c}10-20 y r s \\
\text { nonneoplastic } \\
60-70 y r s \\
\text { benign } \\
\text { 20-30yrs malignant }\end{array}$ & $\begin{array}{c}40-50 \mathrm{yrs} \\
\text { nonneoplastic } \\
41-50 \mathrm{yrs} \\
\\
\text { benign } \\
\text { 20-30yrs malignant }\end{array}$ & $\begin{array}{c}10-20 y r s \\
\text { nonneoplastic } \\
0-10 y r s \\
\\
\text { (benign) } \\
\text { 20-40yrs malignant }\end{array}$ & $\begin{array}{c}\text { Nil (benign) } \\
\text { 30-50yrs } \\
\text { malignant }\end{array}$ \\
\hline $\begin{array}{l}\text { Most common lesion } \\
\text { in individual category }\end{array}$ & $\begin{array}{l}\text { Torsion } \\
\text { Leiomyoma } \\
\text { Seminoma }\end{array}$ & $\begin{array}{c}\text { Torsion } \\
\text { Neurofibroma } \\
\text { Seminoma }\end{array}$ & $\begin{array}{c}\text { Torsion } \\
\text { Nil } \\
\text { Seminoma }\end{array}$ & $\begin{array}{c}\text { c/c nonspecific } \\
\text { epididymoorchitis } \\
\text { Nil } \\
\text { (benign) Seminoma }\end{array}$ \\
\hline
\end{tabular}

Table 2 Distribution of neoplastic lesions of testicular and paratesticular region compared to other studies.

\begin{tabular}{|c|c|c|c|c|c|}
\hline Lesions & $\begin{array}{l}\text { Sheeja et al. } \\
\text { (2019) }\end{array}$ & $\begin{array}{l}\text { Tekumalla et al } \\
(2019)\end{array}$ & $\begin{array}{c}\text { Preeti Rihal } \\
\text { Chakrabarti et al } \\
(2016) \quad[12] \\
\end{array}$ & $\begin{array}{l}\text { Alpaslan Ozgun } \\
\text { et al. } \\
(2013)\end{array}$ & $\begin{array}{l}\text { Karki.S } \\
\text { et al. }{ }^{\text {[14] }} \\
\quad(2012) \\
\end{array}$ \\
\hline Seminoma & $6(30 \%)$ & $6(40 \%)$ & $13(35 \%)$ & $17(17.7 \%)$ & $2(25 \%)$ \\
\hline Mixed germ cell tumour & $3(15 \%)$ & $5(33.3 \%)$ & $12(32.4 \%)$ & $65(67.8 \%)$ & $2(25 \%)$ \\
\hline Yolk sac tumour & $2(10 \%)$ & $1(6.7 \%)$ & $1(2.7 \%)$ & $3(3.1 \%)$ & - \\
\hline Teratoma & $1(5 \%)$ & $2(13.3 \%)$ & $1(2.7 \%)$ & $2(2.1 \%)$ & - \\
\hline Embryonal carcinoma & - & - & - & $9(9.4 \%)$ & - \\
\hline Chorio-carcinoma & - & & - & - & $1(12.5 \%)$ \\
\hline Lymphoma & $2(10 \%)$ & $1(6.67 \%)$ & $6(16.2 \%)$ & - & $2(25 \%)$ \\
\hline Leydig cell tumour & $1(5 \%)$ & & 0 & - & - \\
\hline $\begin{array}{l}\text { Mixedgerm cell sexcord } \\
\text { stromal tumour }\end{array}$ & 0 & & $1(2.7 \%)$ & - & - \\
\hline Leiomyoma & $3(15 \%)$ & & - & - & - \\
\hline Paratesticular sarcoma & $1(5 \%)$ & & $2(5.4 \%)$ & - & - \\
\hline $\begin{array}{l}\text { IMT } \\
\text { (inflammatory } \\
\text { myofibroblastic tumour) }\end{array}$ & $1(5 \%)$ & & - & . & - \\
\hline Others & & & $2(5.4 \%)$ & - & $\begin{array}{l}1(12.5 \%) \\
\text { (leukemic } \\
\text { infiltrate ) }\end{array}$ \\
\hline Total number of tumour & 20 & 14 & 38 & 96 & 8 \\
\hline
\end{tabular}


Figure 1 - Differential diagnosis of testicular and paratesticular lesions

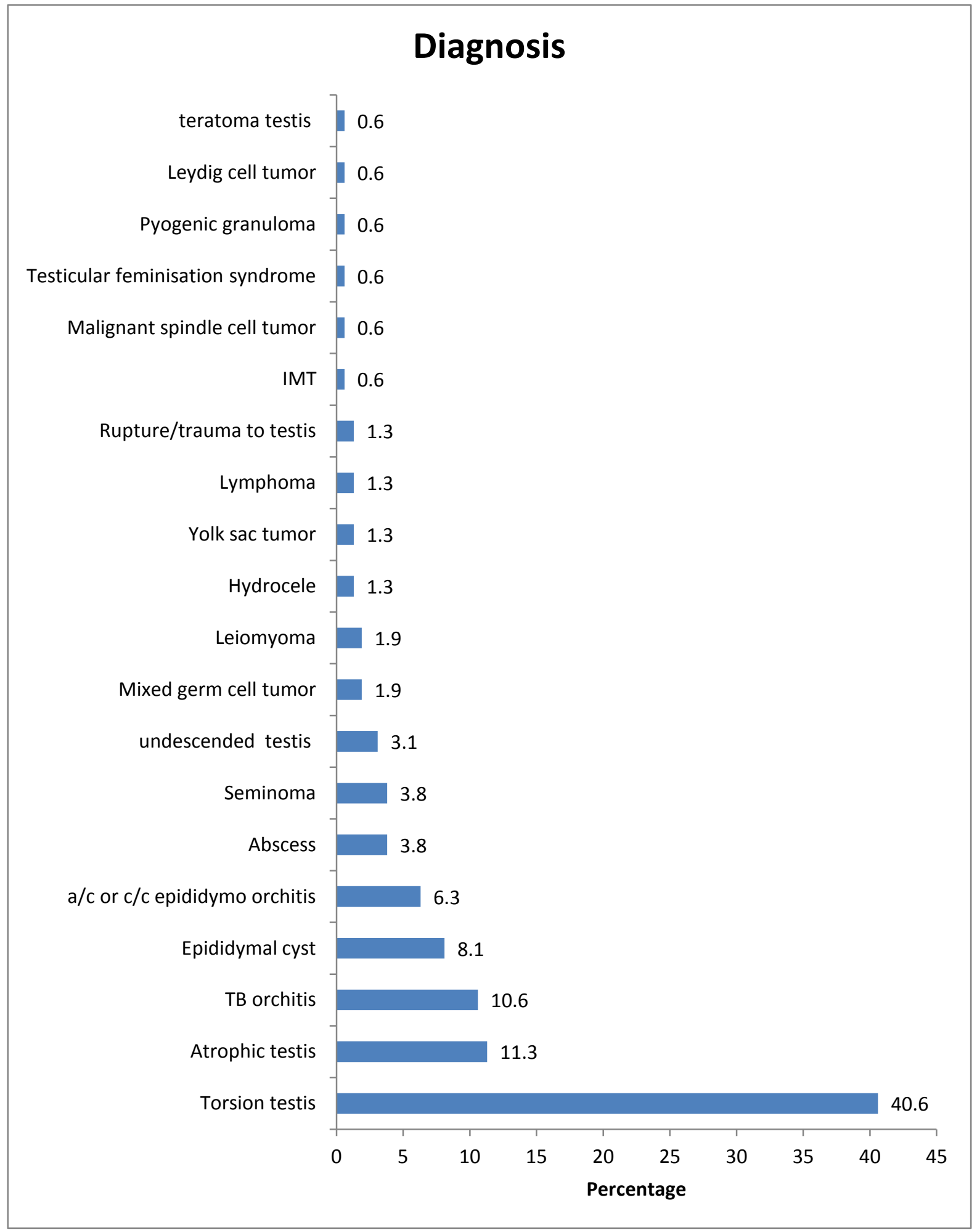



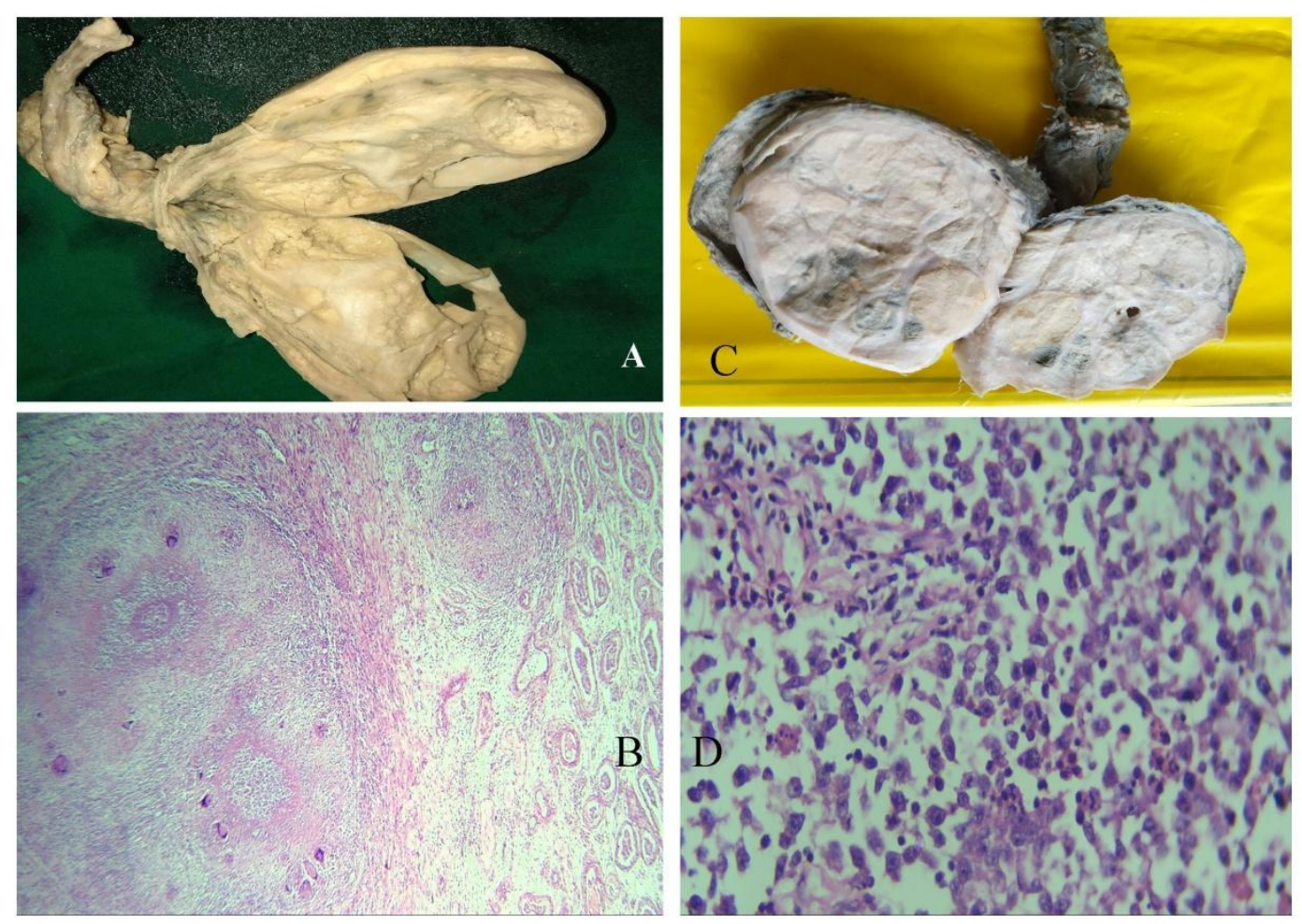

Figure: 2

\section{A-Gross appearance of TB orchitis}

B- Microscopic appearance of TB orchitis with foci of caesating granuloma granulomas. (H\&E,100X)

C- Gross appearance of seminoma

D- Microscopic appearance of seminoma (H\&E, 100X)

\section{Discussion}

There are only limited studies published on testicular and paratesticular lesions from South Asia, including India. Testicular lesions were grouped into non neoplastic and neoplastic with predominant being non neoplastic lesions.

Testicular lesions were present over a wide range of age groups from 8 months to 73 years with maximum in $3^{\text {rd }}$ and $4^{\text {th }}$ decade. In our study the peak incidence of non neoplastic lesions were in 2nd decade and neoplastic lesions in $3^{\text {rd }}$ decade which is comparable with other studies ${ }^{[9,10,11]}$. (Table1). Various studies indicate a decline of testicular malignancy with increase in age, the same trend was seen in our study too.

Testicular and paratesticular lesions were predominantly left sided which is in concordance with that of by Hemavathi Reddy et al $(58 \%)^{[10]}$. Most of lesions were testicular in origin with epididymotesticular involvement by tuberculosis in $9.4 \%$ cases. Painless testicular swelling was the major clinical presentation in neoplastic lesions which was in concordance with other study reports $^{[9]-[12]}$.

Distribution of non neoplastic to neoplastic lesions in our study was 1:7 which was comparable with other recent studies (Table 1). Sundari Devi et al documented a higher incidence of non neoplastic lesions which were mainly of inflammatory in origin.

Torsion testis was the most common cause of orchidectomy in our study affecting 11-20 yrs of age group. The studies from different parts of India showed varied age distribution. Studies by Sundara Devi et al and Tekumalla et al reported chronic non specific epididymo-orchitis as the commonest lesion (21.4\% and $38.5 \%)$ respectively ${ }^{[11,13]}$. 
Atrophic testis was more frequent in our study(12.86\%) and Hemavathi Reddy et al (19.8\%) when compared to Sundara Devi et al. $(5.3 \%)$ and Mahesh et al. (3.5\% ${ }^{[9]-[11]}$. Undescended testis/ maturation arrest in our study was not associated with testicular tumour; though it is a well documented risk factor. None of the major Indian or South Asian studies have documented this association as it is described in western literature ${ }^{[10,14]}$.

Granulomatous epididymo orchitis (12.14\%) due to tuberculosis in our study was more frequent when compared to other studies of Mahesh et al $(9.59 \%), \quad 4.4 \%$ Vijayanirmala et al,(4.4\%),3\% of Hemavati et al(3\%). Testis and epididymis is a site of extrapulmonary tuberculosis. The increasing incidence of tuberculous epididymitis or epididymoorchitis due to rising incidence of immunocompromised patients and HIV infection warrants genitor-urinary TB in the list of common differential diagnosis for a scrotal mass. Isolated epididymoorchitis can produce diagnostic difficulty during the work up of testicular mass.

Neoplastic lesions of testis are very rare when compared to those of other sites. Testicular cancers constitute $0.38 \%$ of total cancer in India $^{[15]}$. Present study showed 20 testicular tumours during our 4 year period with an average of 5 tumou per year. There is marked variation in incidence and mortality of testicular tumours worldwide in last ten years ${ }^{[4,5]}$. A lower incidence with higher mortality seen in Asian and African population compared to European countries. The lower incidence in Asian and African population may be due to lack of risk factors like genetic factors, cryptorchidism, oestrogen rich diet and industrialization compared to western population. The higher mortality may be is due to lack of prompt diagnosis, effective multimodal treatment and surveillance ${ }^{[1,2,12]}$. Reported cancer death in testicular and paratesticular malignancies is only about $0.1 \%$ of cancer deaths in males because the majority of these tumors are curable.

In present study peak age incidence was seen in $4^{\text {th }}$ decade of life and were more common on left side $(75.3 \%)$ comparable with other studies (Table1).The most common malignant tumour seen was seminoma which is comparable with other studies. The most common benign tumor was leiomyoma in our series which occured in a 23 year old man showed a spindle cell neoplasm with hyalinisation and prominent collagen bands with many thin walled blood vessels which aroused a possibility of solitary fibrous tumour.(SFT). IHC studies showed CD34 negative and SMA positive excluded $\mathrm{SFT}^{[7,17.18]}$.

Malignant testicular and paratesticular tumours were less compared to non neoplastic lesions in our study which is comparable to the global statistics. Among the malignant tumors seminoma is the commonest type observed in most studies followed by mixed germ cell tumour similar to that seen in various other studies (Table 2). The predominance of mixed germ cell tumours among non-seminomatous tumours have also been reported in various studies ${ }^{[10],[12]-] 14]}$. Among the mixed non seminomatous germ cell tumour, one case of yolk sac tumour with tetratoma and the other was combination tumour of teratoma, embryonal carcinoma and choriocarcinoma which constituted $5 \%$ of testicular tumors in our study and it is described with grave prognosis. ${ }^{[19,20]}$. Of NSGCT, yolk sac tumour constituted 2 cases followed by tetratoma. Relative frequency of testicular tumour described by different authors show variation may be due to limited number of tumours in each subcategory which can be due the lower incidence of these tumours ${ }^{[19]-[23]}$.

2 malignant paratesticular tumours seen were leiomyosarcoma and a inflammatory myofibroblastic tumour. One of the it was in a 35 year man was circumscribed grey white lesion with microscopy showing plenty of lymphoplasmacytic cells and dense fibrosis. Later 2 findings with obliterative thrombophebitis with increased number of eosinophils aroused a suspicioin of $\mathrm{IgG} 4$ disease .Histopathological diagnosis was given as inflammatory myofibroblastic tumour, it was advised to rule out an IgG4 disease. Later histochemistry showed 
increased number of ig G4 plama cells with igG4/IgG plasma cell ratio $>40 \%$ confirmed the diagnosis of isolated testicular ig G4 disease ${ }^{[24,25]}$. Malignant paratesticular neoplasms do occur rarely (3\%) and including rhabdomyosarcoma, liposarcoma, mesothelioma, and metastasis ${ }^{[7,8,19]}$. None of them were observed in our study series. The most common scrotal sarcomas are rhabdomyosarcoma and liposarcoma. Genital tract lymphoma are rare predominantly seen in the testis and constitute $5 \%$ of all testicular neoplasm ${ }^{[7,8,19]}$. Our study, other than germ cell tumour, lymphomas were the next most common tumour constituting about $10 \%$ with mean age of 73 years. These findings were in accordance with the study series from India and outside which showed Non Hodgkin's lymphoma as the commonest type [12,17,26,27,28] $^{\text {. Sometimes }}$ macroscopic involvement can occur as multiple nodules or as diffuse infiltration. Testis is being more commonly and extensively affected in lymphomas compared to epididymas which help to differentiate it from tuberculosis and sarcoidosis $^{[7]}$.

\section{Conclusion}

The present study shows low frequency of testicular tumours compared to non-neoplastic lesions. Despite newer imaging studies and tumor marker assay, the diagnosis of testicular lesions is primarily dependent upon histopathological examination. The diverse histopathological patterns of testicular lesions is the challenge in offering a specific diagnosis which is of paramount clinical significance. Though testicular mass in young patients is generally considered as malignancy, infectious ethiologies like tuberculous and filarial epididymoorchitis should be considered in the differential diagnosis especially in our country.

\section{References}

1. Park JS, Kim J, Elghiaty, Ham VS .Recent global trends in testicular cancer incidence and mortality. Medicine:2018; 97(37):1-7

2. Freddie Bray, Jacques Ferlay, Isabelle Soerjomataram, Rebecca L. Siegel,et al. Torre. Global cancer statistics 2018: GLOBOCAN estimates of incidence and mortality worldwide for 36 cancers in 185 countries.CA: Cancer Journal for Clinicians.2018; 0:1-31.

3. Yuvaraja TB, Waigankar S, Bakshi G, Prakash G.Genitourinary cancers: Summary of Indian data.South Asian J Cancer. 2016;5:122-4. PMID: 27606296 DOI: $10.4103 / 2278-330 X .187577$

4. Ferlay, J \& Soerjomataram, I \& Ervik, Morten \& Dikshit, Rajesh \& Eser, Parkin, DM \& Forman, David \& Bray, Freddie. (2014). GLOBOCAN 2012 vl.0, cancer incidence and mortality worldwide: IARC cancer base no. 11 [Internet]. International Agency for Research on Cancer, Lyon.

5. Ferlay J, Soerjomataram I, Dikshit R, et al. Cancer incidence and mortality worldwide: sources, methods and major patterns in GLOBOCAN 2012. Int J Cancer 2015; 136: E359- 86.

6. Moch H, Cubilla AL, Humphrey PA, Reuter VE, Ulbright TM.Eur .The 2016 WHO Classification of Tumours of the Urinary System and Male Genital OrgansPart A: Renal, Penile, and Testicular Tumours. Urol. 2016 Jul; 70(1):93-105.

7. Paula J. Woodward, Cornelia M. Schwab, Isabell A. Sesterhenn. From the Archives of the AFIP 216- Extratesticular Scrotal Masses: Radiologic-Pathologic Correlation Radiographics.2003; 23(1):215-40.

8. Mukherjee S, Maheshwari V, Khan R, et al. Clinico-radiological and pathological evaluation of extra testicular scrotal lesions. J Cytol. 2013; 30 (1):27-32. doi:10.4103/0970-9371.107509

9. Mahesh B Patel,H.M. Goswami, U.R. Parikh, N. Mehta. Histopathological Study of Testicular Lesions. Gujarat Medical Journal 2015; 70(1):41-46. 
10. Hemavathi Reddy, Hanishkumar Chawda, VijayD.Dombale. Histomorphological analysis of testicular lesions. Original Research Article.Indian Journal of Pathology and Oncology.2016 (4); 558-63

11. T.Sundari Devi,B.Vijaya Nirmala ,N. Srivani,O.Sharan Kumar. Spectrum of orchidectomy lesions:5 year study. J of Evidence based Med \& healthcare.2015(2)3880-2

12. Preeti Rihal Chakrabarti,Shilpi Dosi, Amit Varma, Priyanka Kiyawat etal. Histopathological Trends of Testicular Neoplasm: An Experience over a Decade in a Tertiary Care Centre in the Malwa Belt of Central India. Journal of Clinical and Diagnostic Research. 2016 (6): EC1618.

13. Tekumalla A, Ragi S, Thota R. Histopathological analysis of testicular lesions- a three year experience in a tertiary care center, Telangana.Trop J Path Micro 2019;5(5):260-8. 14. 6889-92. 10.7314/APJCP.2013.14.11.6889.

14. Karki S, Bhatta RR .Original Article Histopathological analysis of testicular tumors.Journal of Pathology of Nepal .2012(2 ) 301-4.

15. Deotra A, Mathur DR, Vyas MC. 18 years study of testicular tumours in Jodhpur, western Rajasthan. J Postgrad Med. 1994 Apr-Jun;

16. Ozgun, Alpaslan \& Karagoz, Bulent \& Tuncel, Tolga \& Emirzeoğlu, Levent \& Celik, Serkan \& Bilgi, Oguz. Clinicopathological Features and Survival of Young Turkish Patients with Testicular Germ Cell Tumors. Asian Pacific journal of cancer prevention.2013 : APJCP.

17. Al-Daraji W, Husain E, Zelger BG, Zelger B. A practical and comprehensive immunohistochemical approach to the diagnosis of superficial soft tissue tumors. Int J Clin Exp Pathol. 2009;2(2):119-131

18. Geramizadeh B, Marzban M, Churg A. Role of Immunohistochemistry in the
Diagnosis of Solitary Fibrous Tumor, a Review. Iran J Pathol. 2016; 11(3):195293.

19. Sanjay M, Sushma HM. Histopathological spectrum of Tumor and Tumor like lesions of Testis and Paratesticular Structures. A Cross Sectional Study. Indian Journal of Pathology and Oncology. Oct-Dec; 2016; 3(4); 528-534.

20. Trabert B, Stang A, Cook MB, Rusner C, McGlynn KA. Impact of classification of mixed germ-cell tumours on incidence trends of non-seminoma. Int $\mathrm{J}$ Androl. 2011;34 (4 Pt 2):e274-e277.

21. Mushtaq S, Jamal S, Mamoon N, et al. The pathological spectrum of malignant testicular tumours in northern Pakistan. JPak Med Assoc. 2007 Oct;57(10): 499501.

22. Sumat K, Rumana a, Parveen Shah. Clinicopathological. Characteristics of Testicular Tumors. Clin Pathol 2017, 1(1): 1-12

23. Mansi Sharma, Vidhu Mahajan, Jyotsna Suri, KK Kaul. Histopathological Spectrum of Testicular Lesions, A Retrospective study .Indian journal of pathology \& oncology, July - September 2017;4(3):437-441.

24. Lal J, Bhat, Suresh, Doddamani S, Devi L: Isolated Testicular Immunoglobulin G4Related Disease: A Mimicker of Malignancy. Indian J Urol 2016; 32: 326328. [Pubmed]

25. Krishna, Leela \& Krishnamoorthy, Sriram \& Sekar, Hariharasudhan \& Murali, Susruthan \& Swaminathan. Igg4 related disease of epididymis, mimicking testicular malignancy - a rare entity. Annals of urologic oncology; 20191-4. 10.32948/auo.2019.04.26

26. Jamal S, Moghal S, Mamoon N, Mushtaq S, Luqman M, Anwar M. The pattern of malignant tumours: tumour registry data analysis, AFIP, Rawalpindi, Pakistan . J Pak Med Assoc. 2006;56:359-62. 
27. Chia VM, Quraishi SM, Devesa SS, Purdue MP et al. International trends in the incidence of testicular cancer, 19732002. Cancer Epidemiol Biomarkers Prev. 2010;19(5):1151-1159. doi:10.1158/10559965.EPI-10-0031.

28. Kunal S Deore, Mahesh B Patel, Ritesh P Gohil, Kirankumar N Delvadiya, Hansa M Goswami. Histopathological analysis of testicular tumours - a 4 year experience. International Journal of Medical Science and Public Health 2015; Vol 4(4):554-55. 